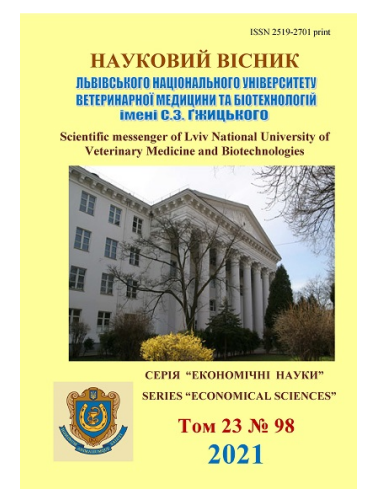

Науковий вісник Дьвівського національного університету
ветеринарної медицини та біотехнологій імені С.З. Гжицького. Серія: Економічні науки

Scientific Messenger of Lviv National University

of Veterinary Medicine and Biotechnologies. Series: Economical Sciences

\title{
Analysis of the hotel industry potential of Lviv region. Prospects for the rural hotels development
}

\author{
T. V. Kalaitan ${ }^{1}$, O. Ya. Hrymak ${ }^{1}$, L. P. Kushnir ${ }^{1}$, R. K. Shurpenkova ${ }^{2}$, O. M. Sarakhman ${ }^{2}$ \\ ${ }^{1}$ Stepan Gzhytskyi National University of Veterinary Medicine and Biotechnologies Lviv, Lviv, Ukraine \\ ${ }^{2}$ University of Banking, Lviv, Ukraine
}

\section{Article info}

Received 10.10.2020

Received in revised form 29.11.2020

Accepted 01.12.2020

Stepan Gzhytskyi National University of Veterinary Medicine and Biotechnologies Lviv, Pekarska Str., 50, Lviv, 79010, Ukraine.

Tel.: +38-097-98-183-60 E-mail:kalaitantv@gmail.com
Kalaitan, T. V.,. Hrymak, O. Ya, Kushnir, L. P., Shurpenkova, R. K., \& Sarakhman, O. M. (2021). Analysis of the hotel industry potential of Lviv region. Prospects for the rural hotels development. Scientific Messenger of Lviv National University of Veterinary Medicine and Biotechnologies. Series: Economical Sciences, 23(97), 23-33. doi: 10.32718/nvlvet-e9804

The hotel industry is one of the most important components of tourism. Its capacity depends on the ability to generate revenue from the full range of tourism services, and, consequently, the success of tourism development at both national and regional levels. Therefore, in this study we would like to assess (1) the hotel sector positioning in the Lviv region by share in the tourist accommodation establishments among the regions of Ukraine; (2) state indicators of Ukraian hotel industry in comparison with similar indicators of the EU member states; (3) the Lviv region position in terms of share in the Ukraine hotel sector among other regions; (4) prospects for the rural hotels development. In the research process we used the systematic review method of scientific publications, Ukrainian legislation, as well as information and analytical materials of international organizations in the tourism field. The hotel sector positioning of Lviv region among other Ukraine regions it is determined on the basis of the studied regions share in the total volume of the country as a whole. The analysis showed that hotels and similar accommodation are the main part of the tourist accommodation establishments potential in the Lviv region. During the study period (2017-2019) the hotel business of Lviv region has a consistently high position among other regions (2nd place). Ranking 2nd in Europe in terms of area, Ukraine ranks 10th in the number of hotels and similar accommodation, and $22 n d$ in the number of beds - among the EU countries, which indicates the insufficient level of the national hotel sector development. The number of hotels in Ukraine is growing slowly. The main reasons for this are: the unstable economic and political situation, the high cost of loans to finance the construction of new hotels, long-term return on investment in hotel real estate and others. The experience of foreign countries with a high level of the hotel sector development shows that state intervention is used to achieve such results. Therefore, in order to develop the hotel sector in Ukraine, it is necessary to develop a program to support it. In particular, in our opinion, fiscal incentives should be introduced (for example, a reduction in the VAT rate for the hotel sector). To increase the tourist flow can be applied the practice of VAT refunds for tourists, reducing VAT rates on passenger transport.

Key words: hotels and similar accommodation, tourist accommodation establishments, tourism, hotel sector, capacity of hotels, fiscal stimulation, rural tourism.

\section{Аналіз потенціалу готельного господарства Львівської області. Перспективи розвитку сільських готелів}

\author{
Т. В. Калайтан ${ }^{1}$, О. Я. Гримак ${ }^{1}$, Л. П. Кушнір ${ }^{1}$, Р. К. Шурпенкова ${ }^{2}$, О. М. Сарахман ${ }^{2}$ \\ 1 Львівський національний університет ветеринарної медицини та біотехнологій імені С. 3. Гюсицького, м. Львів, \\ Украӥна \\ ${ }^{2}$ Університет банківської справи, м. Львів, Украӥна
}


Готельна індустрія є однією з найбільш важливих складових туризму. Від ї̈ потужності залежить можливість отримувати доходи від усього спектру туристичних послуг, а, отже, і успішність розвитку туризму як на національному так $і$ на регіональному рівнях. Тому у даному дослідженні ми хочемо оцінити (1) позиціювання готельного сектору Львівської обл. за часткою в засобах колективного розмішування серед областей Украӥни; (2) показники стану готельного господарства України порівняно з аналогічними показниками країн-членів СС; (3) позииії Львівської області за часткою у готельному секторі України серед інших регіонів; (4) перспективи розвитку сільських готелів. У процесі дослідження ми використовували метод систематизованого огляду наукових публікачій зарубіжних та вітчизняних вчених, законодавства Украӥни, а також інформативно-аналітичних матеріалів міжнародних організачій сфери туризму, консалтингових фірм. Аналітичні розрахунки проводились на основі даних Держстату України та Свростату. Позиціювання готельного сектору Львівскої обл. серед інших областей України визначено на основі частки досліджуваних показників областей у загальному обсязі по краӥні загалом. Проведений аналіз показав, щьо готелі та аналогічні засоби розмішування є основною частиною потенціалу сектору колективних засобів розмішування туристів у Львівській обл. Результати ранжування областей Украӥни за часткою основних показників готельного господарства в їх загальному обсязі по країні загалом за період 2017-2019 рр. показують, щяо протягом досліджуваного періоду готельний сектор Львівщини має серед інших областей стабільно високу позицію (2 місче), поступаючись лише Київській області та значно випереджаючи наступну за рангом Одещзин. Посідаючи 2 місце в Свропі за площею території, Україна за кількістю готелів та аналогічних засобів розміщування займає 10 місие, а за кількістю спальних місиь - 22 місце серед краӥн ЄС, щуо свідчть про недостатній рівень розвитку національного готельного сектору. Зростання кількості готелів в Украӥні відбувається повільними темпами. Основними причинами цуього є: нестабільна економічна та політична ситуація, висока вартість кредитів для фінансування будівництва нових готелів, тривала окупність інвестицій в готельну нерухомість та інші. Досвід зарубіжних краӥн з високим рівнем розвитку готельного сектору показує, щуо для досягнення таких результатів застосовується втручання з боку держави. Тому з метою розвитку готельного сектору в Україні необхідне розроблення програми його підтримки. Зокрема, на нашу думку, слід запровадити фіскальне стимулювання (наприклад, зниження ставки ПДВ для готельного сектора). Для збільшення туристичного потоку може бути застосована практика відшкодування ПДВ для туристів, зниження ставок ПДВ на транспортні перевезення пасажирів.

Ключові слова: готелі та аналогічні засоби розмішування, колективні засоби розмішування, туризм, готельний сектор, місткість готелів, фіскальне стимулювання, сільський туризм.

\section{Вступ}

Актуальність теми. Як відомо, сфера туризму (до спалаху коронавірусу) забезпечувала більше $10 \%$ світового ВВП. Готельна індустрія належить до найбільш крупного сектору сфери туризму - колективних засобів розміщування. Від іiі потужності залежить можливість приймати та обслуговувати туристів, а, отже, і отримувати доходи від усього спектру туристичних послуг. У багатьох країнах саме вартість наданих готелями послуг з розміщування або кількість проведених ночівель $є$ базою оподаткування туристичним збором, i, таким чином, додатковим джерелом наповнення державного бюджету. У 2019 р. світова готельна індустрія отримала виручку від продажу номерів в розмірі 550 млрд. доларів, що стало рекордом і на 2,5 \% більше, ніж у 2018p. (2019 Global Hotel Study, 2020). Додатковий вплив готельного бізнесу на національні економіки здійснюється також через витрати гостей, крім оплати вартості проживання. Так, у 2018p. на кожні 100 дол., потрачених на оплату за проживання в готелях США, туристи тратили ще 222 дол. під час подорожі, що загалом складає 564,9 млрд. доларів (Hotel management, 2020).

До початку 2020 року світова готельна індустрія була надзвичайно успішною. Продуктивність готелів протягом 2007-2019 рр. залишалась стабільною, а рівень завантаження майже на 5\% перевищив рівень попереднього піку у 2007 р. (2019 Global Hotel Study, 2020). За останні 10 років (до спалаху коронавірусу) цей сектор був найбільш динамічним щодо створення робочих місць. Наприклад, у 2018 р. готельна індустрія США забезпечувала роботою більше ніж одне 325 робочих місць. Тут в 2018 р. безпосередньо працювали 2,3 млн. чол., що на 7 \% більше ніж у 2015 р. і на $14 \%$ більше ніж у 2005 р. (Hotel management, 2020). Готельна індустрія є трудомісткою і тому зростання в цій сфері значно впливає на зайнятість. Отже, готельний сектор виконує важливу соціальну функцію забезпечення зайнятості населення.

Готельний бізнес ЄС до спалаху коронавірусу також мав стійкий розвиток. Протягом останніх 3-х років темп зростання доходів готельного сектору СС складав близько 3,1 \%. Доходи готельного сектору СС у 2019 р. склали 102,33 млрд дол. У 2019 р. порівняно 32018 р. за всіма категоріями готелів СС спостерігалось зростання доходу на доступний номер за день (RevPAR) на 2,2 \%, зокрема, на 1,6 \% для пяти зірок, на 3,0 \% для чотирьох зірок, на 3,3 \% для трьох зірок (HOTREC Annual Report, 2020).

В Україні у 2017p. загальний обсяг послуг, наданих готелями, складав 0,28 \% по відношенню до ВВП (Derzhstat Ukrainy, 2018; Minfin, 2021). Для порівняння, в США у 2017p. аналогічний показник склав 1,06 \% (CoStar, 2020a; Countryeconomy.com, 2020). У Львівській області цей показник склав у 2017p. 0,88 \% (Derzhstat Ukrainy, 2018; Holovne upravlinnia satystyky u Lvivskii obl., 2018), що значно вище від середнього значення по Україні та співвимірно 3 аналогічним показником в США.

Аналіз останніх досліджень та публікацій. Вагомий вплив готельного бізнесу на соціальноекономічне становище суспільства визначає інтерес до цього сектору з боку дослідників. Різноманітні аспекти розвитку потенціалу готельного бізнесу $\epsilon$ обєктом наукових інтересів багатьох вчених всього світу. Частина наукових праць стосується історичних аспектів формування потенціалу цього сектору туризму. Так, дослідженню витоків готельного бізнесу в Іспанії присвячена робота (Larrinaga \& Vallejo, 2020). Ці вчені повідомляють, що в кінці 19 - початку 20 ст. готельні заклади не були орієнтовані на туризм і лише 3 його розвитком можна говорити про формування потужного потенціалу готельного сектору в Іспанії і в Західній Свропі (Bowie, 2018) у своїй праці розглядає 
історичні трансформації готельної індустрії в Англії протягом 19-20 ст.

Окремі аспекти забезпечення зайнятості в готельному бізнесі досліджували Melián-González \& Bulchand-Gidumal (2020), Dogru et al. (2020), Papadopoulos \& Lyddon (2020), Fortanier \& van Wijk (2010) та багато інших вчених.

Частина наукових досліджень присвячена питанням аналізу впливу факторів на прибутковість та фінансовий стан підприємств готельного бізнесу (Arbelo, et al., 2017; Karanovic, et al., 2018; He et al., 2019, Botta, 2019, Mun et al., 2019; Casado-Díaz \& Sellers-Rubio, 2020; Kalaitan, 2020) та інші. Так, Karanovic et al. (2018) провели аналітичну оцінку відносних фінансових показників готелів Хорватії. Результати аналізу свідчать про те, що готельний сектор цієї країни має високу частку позикових коштів та низьку ліквідність, незважаючи на значний ріст інвестицій. Ці проблеми (Karanovic et al., 2018) повязують з незавершеним переходом деяких готельних компаній до вільної ринкової економіки. Botta (2019) дослідив структуру капіталу малого та середнього бізнесу в готельному секторі Італії і прийшов до висновку, що вона не відповідає оптимальному співвідношенню, яке максимізує прибуток інвесторів.

He et al. (2019) повідомляють про вплив зміни кліматичних умов на прибуток в готельному бізнесі США за період 2016-2018 pp. Mun et al. (2019) дослідили вплив наявності додаткових послуг з харчування в готелях США на підвищення операційних доходів від оренди номерів. Casado-Díaz \& Sellers-Rubio (2020) вивчили вплив короткострокової оренди на ефективність готельного сектору Іспанії. Ці вчені дійшли до висновку, що більша кількість короткострокової оренди повязана з більшою технічною ефективністю готелів. Arbelo et al. (2017) порівнюють рівень витрат і прибутку готелів Іспанії з передовою практикою. Результати показують, що рівні ефективності прибутку готелів Іспанії значно нижчі, ніж рівні ефективності витрат. Vargas-Hernández et al. (2019) провели конкурентний аналіз готельних мереж Мексики. Li (2015) дослідив можливі ризики інвестування в будівництво агроготелів та заходи щодо їх уникнення.

Частина наукових праць присвячена аналізу впливу спалаху коронавірусу на економічний стан готельної індустрії. Так, Anguera-Torrell et al. (2020) провели аналіз доходності 20 найбільш крупних світових готельних компаній, зареєстрованих на фондовій біржі. Результати дослідження показали, що COVID-19 негативно повпливав на стан готельного сектору. Разом 3 тим ціни на акції позитивно корелюють $з$ економічною політикою, яка спрямована на підтримку готельного бізнесу, що свідчить про високий рівень чутливості цього сектору туризму. Gursoy \& Chi (2020) дослідили можливості відновлення індустрії гостинності з точки зору готовності населення до мандрів.

Питання корпоративної соціальної відповідальності та впровадження стратегій сталого розвитку в готельному секторі досліджували Serra-Cantallops et al. (2018), Baicu et al. (2019), Mak \& Chang (2019), Kalaitan et al. (2021) та інші вчені. Впровадження екологічних методів проектування та будівництва готелів, які створюють зелене середовище і навіть сприяють підвищенню їх фінансового стану стану, вивчали Ahn \& Pearce (2013), Mariño-Romero et al. (2018) визначили ступінь позитивного впливу усвідомлення керівництвом готелів екологічної відповідальності на прибутковість готельного бізнесу.

Мета та завдання. Метою статті є дослідження потенціалу готельного господарства Львівської області та перспектив розвитку сільських готелів. Для цього ми хочемо оцінити (1) позиціювання готельного сектору Львівської обл. за часткою в засобах колективного розміщування серед областей України; (2) показники стану готельного господарства України порівняно з аналогічними показниками країн-членів СС; (3) позиції Львівської області за часткою у готельному секторі України серед інших регіонів; (4) перспективи розвитку сільських готелів. Таке дослідження дасть змогу визначити позиціювання готельного сектору Львівської області серед інших регіонів України, виявити існуючі проблеми в діяльності національного готельного бізнесу та запропонувати шляхи їх вирішення.

\section{Матеріал і методи досліджень}

У процесі дослідження ми використовували метод систематизованого огляду наукових публікацій зарубіжних та вітчизняних вчених, законодавства України, а також інформативних матеріалів міжнародних організацій сфери туризму (World Tourism Organization, HOTREC), аналітичні матеріали міжнародних консалтингових фірм (CoStar Realty Information, CoStar Group, Inc, Statista.com, PricewaterhouseCoopers LLP), матеріалів наукових конференцій за вказаною темою.

Інформаційною основою для проведення аналізу потенціалу готельного господарства Львівщини є дані Державної служби статистики та Державної податкової служби України. У даному дослідженні ми провели аналіз потенціалу готелів та аналогічних засобів розміщування. Відповідно до термінології вітчизняної статистики готелі та аналогічні засоби розмімування - це колективні засоби розміщування, що складаються більше ніж із семи номерів; мають єдине керівництво; надають готельні послуги, зокрема обслуговування в номерах, щоденне заправляння ліжок та прибирання кімнат і санвузлів; згруповані в класи і категорії відповідно до переліку надаваних послуг і наявного устаткування і не входять до категорії спеціалізованих закладів (Derzhstat Ukrainy, 2011). Номер (готелю) - окреме вмебльоване приміщення з однієї чи кількох кімнат, оснащене обладнанням та інвентарем для надання послуг з тимчасового розміщування. Агроготель - це готель, розташований у сільській місцевості, який має умови для сільськогосподарсткої діяльності під час відпочинку (DSTU 4527: 2006, 2006).

Статистичні спостереження 3 надання послуг розміщування здійснюються органами Державної служби статистики України на основі статистичної форми звітності №1-КЗР (річна) “Звіт про діяльність колек- 
тивного засобу розміщування". Відповідно до Наказу Держстату України від 16.07.2018 №152 (Nakaz Derzhstatu Ukrainy, 2018) форму №1-КЗР подають до органів Державної статистики 32018 р. лише юридичні особи та їх відокремлені підрозділи (до 2018 р. ця форма звітності подавалась як юридичними, так i фізичними особами-підприємцями). Таким чином, починаючи 32018 р. на сайті Держстату України інформація по колективних засобах розміщування у розрізі областей подається лише стосовно юридичних осіб (і без виокремлення статистичних даних по агроготелях). Загальну кількість готелів та аналогічних засобів розміщування з 2018 р. визначають на основі даних Державної служби статистики (по юридичних особах) та Державної податкової служби України (по фізичних особах-підприємцях).

Крім того з метою гармонізації вітчизняної статистики колективних засобів розміщування до практики ЄС до готелів та аналогічних засобів розміщування 3 2018 р. відносяться лише готелі та мотелі. До 2018 р. до групи "Готелі і аналогічні засоби розміщування" включали: готелі, мотелі, хостели, кемпінги, агроготелі, гуртожитки для приїжджих, туристські бази, гірські притулки, студентські літні табори та інші засоби тимчасвого розміщування.

Таким чином, статистичні дані Державної служби статистики України за окремі періоди мають різну структуру, що суттєво ускладнює проведення аналізу потенціалу готельного сектору в динаміці за більш тривалий період. Тому оцінку потенціалу готельного сектору Львівської області серед інших областей України ми проводили на основі показників готелів та мотелів зі статусом юридичної особи за період 2017 2019 рр. Дані спеціального статистичного збірника (Derzhstat Ukrainy, 2018) дозволили виділити за 2017 р. показники діяльності готелів та аналогічних засобів розміщування зі статусом юридичної особи.

3 метою порівняння 3 показниками розвитку готельного бізнесу в СС було використано дані Свростату. Відповідно до п. 2.2.1.1 NACE 55.1 -Методологічного керівництва зі статистики Туризму СC (Eurostat, 2014) до готелів та аналогічних засобів розміщування відносять: готелі, курортні готелі, люкс-готелі, мотелі. Цей клас включає надання мебльованого житла, як правило, для короткострокового перебування гостей. До послуг входять щоденне прибирання та підготовка постелі. Низка додаткових послуг включає харчування, парковку, послуги пральні, басейни і тренажерні зали, місця для відпочинку, конференц-зали. Вирішальною компонентою засобів розміщування цього класу є надання додаткових послуг, особливо регулярне прибирання та підготовка постелі щоденно.

Оцінку позиціювання підприємств готельного бізнесу Львівщини серед інших областей України було здійснено на основі визначення частки досліджуваних показників діяльності цього сектору сфери туризму в загальному обсязі даного показника по Україні загалом за підходом, викладеним у монографії Herasymenko et al. (2016). Частку досліджуваних показників області у загальному обсязі по країні визначено за формулою:

$$
\mathrm{Y}_{1}=\frac{\Pi_{1}}{\sum_{1}^{p} \Pi_{1} \Pi_{1}} * 100 \%,
$$

де $\Pi_{i}-$ досліджуваний показник по і-тій області України,

$\sum_{i=1}^{n} \Pi_{\mathbf{i}}-$ сумарний досліджуваний показник загалом по Україні.

$\mathrm{n}$ - кількість областей,

i - порядковий номер області.

На основі отриманих значень частки досліджуваних показників діяльності підприємств готельного бізнесу визначено місце Львівщині серед інших областей України та проведено порівняння $з$ практикою EC.

За аналогічною формулою визначено частку основних показників, що характеризують потенціал готелів та аналогічних засобів розміщування, в загальному обсязі показників, що характеризують потенціал колективних засобів розміщування.

\section{Результати та їх обговорення}

\section{1. Позиціювання готельного сектору серед ін- ших засобів колективного розміщування}

Готельний сектор є вагомим складовим елементом колективних засобів розміщування. У 2019 р. частка місць в готелях та мотелях Україні складала 40,5 \% від кількості місць в усіх колективних засобах розміщування, в СС - 42,9 \%. У 2019 р. в СС готелі та аналогічні засоби розміщування були найбільш популярними серед туристів, частка ночівель в них серед інших колективних засобів розміщування склала 64,5 \%, при цьому на Кіпрі, Мальті та в Болгарії готелі та аналогічні засоби розміщування складали більше 90 \% національного потенціалу колективних засобів розміщування (Eurostat, 2020). В Україні за кількістю ночівель частка готельного сектору у 2019 р. склала $56,6 \%$.

Для визначення позиціювання готельного сектору Львівської області у колективних засобах розміщування серед інших областей України ми провели ранжування за часткою основних показників готельної індустрії у загальному обсязі показників, що характеризують потенціал всіх колективних засобів розміщування. Результати ранжування відображено у табл. 1.

За часткою спальних місць у готельному секторі серед всіх колективних засобів розміщування Львівська обл. має найбільше значення по Україні - 86,7 \% (по Україні цей показник складає - 40,5 \%). При цьому за кількістю готелів та мотелів Львівська обл. займає 4 місце (81,5 \%) поступаючись Житомирській (89,5 \%), Рівненській (83,3 \%), Закарпатській (83,1%). Це свідчить про більшу місткість готелів Львівської області порівняно з Житомирською, Рівненською та Закарпатськю областями. Загалом в областях Західної України прослідковується тенденція переважання частки місць готелів і мотелів в загальній кількості місць колективних засобів розміщування. Слідом за Львівською обл. йдуть Закарпатська (77,9 \%), ІваноФранківська (75,9 \%), Тернопільська (69,0 \%), Київська обл. має $65,1 \%$. Частка готельного сектору у загальній кількості ночівель в колективних засобах розміщування Львівщини у 2019 р. склала 95,3 \% (1 міс- 
це), Київської області - 94,6 \%. Такі результати свідчать про те, що готельний бізнес $є$ основною части- ною потенціалу колективних засобів розміщування туристів у Львівській обл.

\section{Таблиця 1}

Ранг окремих областей України за часткою готельного сектору в колективних засобах розміщування за 2019 рік*

\begin{tabular}{|c|c|c|c|c|c|c|}
\hline \multirow{2}{*}{\multicolumn{2}{|c|}{ Показник }} & \multicolumn{5}{|c|}{ Ранг окремих областей України } \\
\hline & & I & II & III & IV & $\mathrm{V}$ \\
\hline $\begin{array}{l}\text { 1.Готелі та аналогіч- } \\
\text { ні засобів розміщу- } \\
\text { вання }\end{array}$ & $\begin{array}{c}\text { Область } \\
\text { Частка, \% }\end{array}$ & $\begin{array}{c}\text { Житомирська } \\
89,5\end{array}$ & $\begin{array}{c}\text { Рівненська } \\
83,3\end{array}$ & $\begin{array}{c}\text { Закарпатська } \\
83,1\end{array}$ & $\begin{array}{c}\text { Львівська } \\
81,5\end{array}$ & $\begin{array}{c}\text { Хмельницька } \\
77,4\end{array}$ \\
\hline $\begin{array}{l}\text { 2. Загальна кількість } \\
\text { місць }\end{array}$ & $\begin{array}{c}\text { Область } \\
\text { Частка, \% }\end{array}$ & $\begin{array}{c}\text { Львівська } \\
86,7\end{array}$ & $\begin{array}{c}\text { Закарпатська } \\
77,9\end{array}$ & $\begin{array}{c}\text { Івано- } \\
\text { Франківська } \\
75,9\end{array}$ & $\begin{array}{c}\text { Тернопільська } \\
69,0\end{array}$ & $\begin{array}{c}\text { Житомирська } \\
68,6\end{array}$ \\
\hline $\begin{array}{l}\text { 3. Загальна кількість } \\
\text { обслуговуваних } \\
\text { приїжджих }\end{array}$ & $\begin{array}{c}\text { Область } \\
\text { Частка, \% }\end{array}$ & $\begin{array}{c}\text { Львівська } \\
96,9\end{array}$ & $\begin{array}{c}\text { Хмельницька } \\
94,8\end{array}$ & $\begin{array}{c}\text { Київська } \\
94,7\end{array}$ & $\begin{array}{c}\text { Полтавська } \\
93,1\end{array}$ & $\begin{array}{c}\text { Чернігівська } \\
91,6\end{array}$ \\
\hline $\begin{array}{l}\text { 4.Кількість обслуго- } \\
\text { вуваних іноземців }\end{array}$ & Область & $\begin{array}{c}\text { Хмельницька, } \\
\text { Полтавська, Рівне- } \\
\text { нська, Сумська, } \\
\text { Волинська, Кірово- } \\
\text { градська, Луганська } \\
100.0\end{array}$ & Черкаська & $\begin{array}{c}\text { Чернігівська, } \\
\text { Дніпропетровсь- } \\
\kappa a,\end{array}$ & Запорізька & Вінницька \\
\hline $\begin{array}{l}\text { 5. Кількість ночівель } \\
\text { осіб }\end{array}$ & $\begin{array}{l}\text { Область } \\
\text { Частка, \% }\end{array}$ & $\begin{array}{l}\text { Львівська } \\
95,3\end{array}$ & $\begin{array}{l}\text { Киїська } \\
94,6\end{array}$ & $\begin{array}{l}\text { Закарпатська } \\
86,5\end{array}$ & $\begin{array}{c}\text { Сум,о } \\
86,1\end{array}$ & $\begin{array}{c}\text { Тернопільська } \\
84,3\end{array}$ \\
\hline $\begin{array}{l}\text { 6. Кількість ночівель } \\
\text { іноземців }\end{array}$ & Область & $\begin{array}{c}\text { Киівська, Полтав- } \\
\text { ська, Хмельницька, } \\
\text { Кіровоградська, } \\
\text { Сумська, Рівненсь- } \\
\text { ка, Луганська, } \\
\text { Волинська } \\
100.0\end{array}$ & Черкаська, & $\begin{array}{c}\text { Дніпропетровсь- } \\
\kappa a\end{array}$ & Вінницька & $\begin{array}{c}\text { Івано- } \\
\text { Франківська, } \\
\text { Чернігівська }\end{array}$ \\
\hline
\end{tabular}

За часткою приїжджих, що перебували в готелях та мотелях, у загальній кількості приїжджих, що перебували у колективних засобах розміщування, Львівська область також посідає 1 місце $(96,9$ \%), 2 місце належить Хмельницькій області (94,8 \%), по Україні - 80,2%. За часткою іноземців, які перебували у готелях та мотелях у загальній кількості іноземців, що перебували у колективних засобах розміщування, Львівська обл. займає 7 місце $(99,1 \%)$; значення цього показника по Україні - 97,9 \%. За кількістю ночівель іноземців у готелях та мотелях Львівська обл. посідає 6 місце (частка складає 99,4 \%), значення по Україні - 95,3\%.

Отже, результати проведених розрахунків показують, що готелі та мотелі у Львівській області серед інших колективних засобів розміщування займають більшу частку за кількістю закладів $(81,7$ \%), за кількістю місць $(86,7 \%)$, за кількістю приїжджих, що перебували в готелях та мотелях (96,9 \%), та за кількістю ночівель приїжджих $(95,3 \%)$ що значно відрізняється від аналогічних показників загалом по Україні (48,7 \%, 40,5\%, 80,2 \%, 56,6 \% відповідно). Частка кількості іноземців, які перебували у готелях та мотелях, у загальній кількості іноземців, що перебували у колективних засобах розміщування Львівської області значно не відрізняється від значення по Україні (99,1 \% і 97,9 \%). Це свідчить про те, що іноземці (не залежно від області, до якої вони подорожують) віддають перевагу розміщуванню в готелях та мотелях.

\section{2. Аналіз місткості готелів та аналогічних засо- бів розміщування}

Україна у 2019 р. за кількістю готелів та аналогічних засобів розміщування (3165 готелів, фізичних та юридичних осіб) посідає 10 місце, за кількістю місць - 22 місце серед країн СС (табл. 2). Такий великий розрив свідчить про відносно меншу місткість готелів та мотелів України порівняно з СС. Загальна кількість готелів та аналогічних засобів розміщування в СС у 2019 р. склала 163193 одиниці. Безумовними лідерами в Європі за цим показником є Великобританія (39 715 готелів у 2018 р.), Італія (32 730 готелів у 2019 р.), Німеччина (32 182 готелів у 2019p.). При цьому 50 \% від усіх спальних місць у готелях Свропи припадає на Великобрітанію, Італію та Іспанію (Eurostat, 2020).

Сусідня з Україною Польща має 4229 готелів та аналогічних засобів розміщування, Чехія, яка значно менше за розмірами ніж Україна, має 6236 готелів. Враховуючи, що Україна займає 2 місце в Свропі за площею території і має такі позиції, можемо зробити висновок про недостатній рівень розвитку готельного сектору по Україні загалом. 
Таблиця 2

Місткість готелів та аналогічних засобів розміщування країн ЄС та України у 2019 р.*

\begin{tabular}{|c|c|c|c|c|}
\hline Країна & $\begin{array}{c}\text { Кількість готелів та аналогічних засобів } \\
\text { розміщування } \\
\end{array}$ & Місце & $\begin{array}{l}\text { Кількість спальних } \\
\text { місць }\end{array}$ & Місце \\
\hline Італія & 32730 & 1 & 2260490 & 1 \\
\hline Німеччина & 32182 & 2 & 1889315 & 3 \\
\hline Іспанія & 19683 & 3 & 1954825 & 2 \\
\hline Франція & 17960 & 4 & 1308956 & 4 \\
\hline Австрія & 11823 & 5 & 607010 & 6 \\
\hline Греція & 9892 & 6 & 841114 & 5 \\
\hline Чехія & 6236 & 7 & 328501 & 9 \\
\hline Польща & 4229 & 8 & 368944 & 7 \\
\hline Нідерланди & 3806 & 9 & 303713 & 10 \\
\hline Україна & 3165 & 10 & 75667 & 22 \\
\hline Румунія & 2857 & 11 & 225699 & 13 \\
\hline Португалія & 2401 & 12 & 362247 & 8 \\
\hline Угорщина & 2324 & 13 & 184090 & 14 \\
\hline Болгарія & 2166 & 14 & 288027 & 11 \\
\hline Швеція & 2143 & 15 & 260436 & 12 \\
\hline Ірландія & 1992 & 16 & 158511 & 16 \\
\hline Словакія & 1731 & 17 & 108876 & 19 \\
\hline Словенія & 1508 & 18 & 62723 & 23 \\
\hline Бельгія & 1505 & 19 & 137484 & 18 \\
\hline Хорватія & 1089 & 20 & 171005 & 15 \\
\hline Кіпр & 814 & 21 & 89200 & 21 \\
\hline Фінляндія & 794 & 22 & 143023 & 17 \\
\hline Данія & 585 & 23 & 104702 & 20 \\
\hline Литва & 494 & 24 & 39689 & 25 \\
\hline Естонія & 450 & 25 & 35909 & 26 \\
\hline Латвія & 348 & 26 & 27315 & 27 \\
\hline Люксембург & 227 & 27 & 15350 & 28 \\
\hline Мальта & 224 & 28 & 46350 & 24 \\
\hline
\end{tabular}

*Джерело: Складено авторами за даними Свростату (Eurostat, 2020) та Державної служби статистики України (Derzhstat Ukrainy, 2020a)

Зростання кількість готелів та аналогічних засобів розміщування (готелі і мотелі, юридичні особи) в Україні на даному етапі відбувається повільними темпами (рис. 1). У Львівській обл. динаміка зміни кількості готелів має негативний напрям (за період 2017-2019 рр. зниження з 108 до 106 одиниць). Готельний сектор Львова характеризується переважанням невеликих за розмірами готелів з середньою кількістю номерів близько 42. Номерний фонд (юридичні та фізичні особи-підприємці) налічує близько 5000 номерів. Іноземних інвесторів немає, оскільки їх цікавить вкладння коштів в готелі з ємністю від 100 номерів, що економічно більш вигідно (Inozemtsi u lvivski hoteli..., 2020).

Повільние зростання кількості готелів в Україні пояснюється різними причинами. Серед факторів, що гальмують появу нових готелів $є$ такі: тривала окупність, значні витрати на розвиток і операційну діяльність (велику частку в структурі яких складають витрати на імпортну продукцію), політична та фінансова ситуація в країні, а також недосконалість законодавчої бази в частині міжнародних інвестицій та розвитку туристичного бізнесу в Україні. Найбільшим стримуючим фактором $\epsilon$ великий період окупності нового готелю. У сучасних економічних умовах він складає не менш ніж 10 років (Kontakty, 2020). 3 метою скорочення терміну окупності готельєри намагаються підвищувати ціни. Як повідомляють Moldovanov \& Tkachuk (2017) ціни в українських готелях вищі за середньоєвропейські, а рівень обслуговування не відповідає міжнародним стандартам, i, навіть, переважно нижчий. Із 8700 номерів столичних готелів лише 3 \% відповідають міжнародним стандартам. При цьому вартість готельних послуг становить у Києві від \$ 170 до \$ 450 за добу, і вона постійно зростає.

3 метою сприяння збільшенню інвестицій в будівництво нових готелів в світовій практиці застосовуються пільгові ставки амортизації. Така практика діє, наприклад, в Австралії вже понад 30 років. Для підтримки готельного сектору з боку держави у переважній більшості країн $€ С$ застосувється режим пільгового оподаткування ПДВ. Так, у Німеччині співвідношення ставки ПДВ “стандартна/пільгова для готелів складас $19 \% / 7 \%$, в Естонії $20 \% / 9 \%$, в Іспанії $21 \% / 10 \%$, в Італії $22 \% / 10 \%$, у Польщі $23 \% / 8 \%$, у Португалії $23 \% / 6 \%$ \%. Крім того в деяких країнах ЄС 3 метою стимулювання туристичного потоку застосовують зниження ставок ПДВ на транспортні перевезення пасажирів (PwC, 2017). Досвід Свропи демонструє позитивний вплив зниження ставок ПДВ для індустрії гостинності на підтримання зайнятості населення, стабільних споживчих цін, інвестицій. Наприклад, у 2009 р. розмір капітальних вкладень готелів Німеччини складав близько 90000 євро, у 2011 р. (після введення у 2010 р. пільгової ставки ПДВ для послуг розміщування) ця цифра зросла до 243000 євро. Інвестиції було зроблено в основному у прид- 
бання нових машин та устаткування, а також в ремонт та модернізацію номерів (FoodDrinkEurope, 2020).

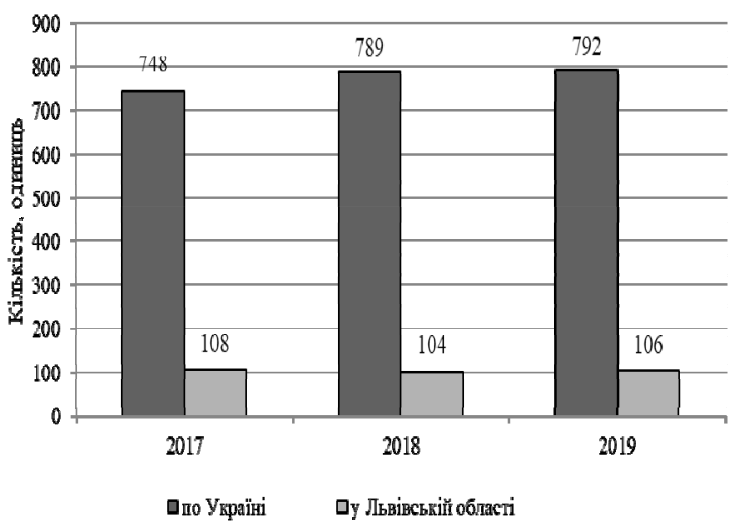

Рис. 1. Динаміка кількості готелів та мотелів (юридичних осіб) по Україні та у Львівській області за період 2017-2019 рр.

Джерело: Сформовано авторами на підставі даних Державної служби статистики України (Derzhstat Ukrainy, 2018; Derzhstat Ukrainy, 2020b)

Наведені дані показують, що готельний бізнес у тих країнах, де застосовується державна підтримка, зокрема, пільговий режим оподаткування, демонструє кращі експлуатаційні показники. Для українскої практики, враховуючи наявні протиріччя фіскального законодавства (Yaroshevych et al., 2019), доцільним є також розроблення ефективного механізму податкового стимулювання малого бізнесу, оскільки діяльність 3 надання послуг тимчасового розміщування здійснюється в основному субєктами малого підприємництва.

В посткарантинний період (з липня 2020 р.) в деяких країнах Європи для готелів тимчасово знижені навіть пільгові ставки ПДВ, наприклад у Німеччині, Австрії, Кіпрі - до 5 \%, у Болгарії, Норвегії - до $6 \%$, у Чехії - до 10 \%; у Турції до рекордно низького рівня - 1 \% (FoodDrinkEurope, 2020). В Україні тимчасовий пільговий режим оподаткування податком на додану вартість для засобів тимчасового розміщування був введений лише 31 січня 2021p. Ставка ПДВ знижена 3 $20 \%$ до 7 \% до 1 січня 2023 р. (Zakon Ukrainy, 2020).

\section{3. Позиціювання готельного сектору Львівської} області серед інших областей України

Результати розрахунків частки основних показників діяльності підприємств готельного бізнесу Львівщини у їх загальному обсязі по Україні за період 2017-2019 pр. наведено у табл. 3. Протягом досліджуваного періоду готельний бізнес Львівщини має стабільно високу позицію (2 місце) за всіма досліджуваними показниками, поступаючись лише Київській області. Якщо порівняти показники Львівщини 3 середнім статистичним значенням кожного показника $(100: 24=4,2 \%)$, то видно, що даному регіону належить вагома частка в масштабах всієї країни (від 13,2 \% до 18,7 \% за різні роки). Значення всіх показників в динаміці мають невеликі коливання. Це свідчить про те, що готельний бізнес Львівщини протягом досліджуваного періоду має стабільно потужну позицію серед інших областей України.

\section{Таблиця 3}

Позиціювання Львівської області серед інших областей України за основними показниками діяльності готелів та аналогічних засобів розміщування (юридичні особи) за 2017-2019pр.*

\begin{tabular}{|c|c|c|c|c|c|c|}
\hline \multirow{2}{*}{ Показник } & \multicolumn{2}{|c|}{2017 рік } & \multicolumn{2}{|c|}{2018 рік } & \multicolumn{2}{|c|}{2019 рік } \\
\hline & Частка, $\%$ & Ранг & Частка, $\%$ & Ранг & Частка,\% & Ранг \\
\hline $\begin{array}{l}\text { 1.Кількість готелів } \\
\text { засобів розміщування }\end{array}$ & 14,4 & 2 & 13,2 & 2 & 13,4 & 2 \\
\hline 2. Загальна кількість місць & 15,9 & 2 & 15,4 & 2 & 15,1 & 2 \\
\hline 3. Кількість номерів & 14,9 & 2 & 14,3 & 2 & 14,3 & 2 \\
\hline $\begin{array}{l}\text { 4.Загальна } \text { кількість обслуговуваних } \\
\text { приїжджих }\end{array}$ & 14,2 & 2 & 14,6 & 2 & 14,0 & 2 \\
\hline 5.Кількість обслуговуваних іноземців & 14,2 & 2 & 16,4 & 2 & 14,7 & 2 \\
\hline 6.Кількість ночівель, осіб & 18,0 & 2 & 18,7 & 2 & 18,1 & 2 \\
\hline 7.Кількість ночівель іноземців & 13,6 & 2 & 17,1 & 2 & 17,5 & 2 \\
\hline 8.Коефіцієнт використання місткості* & 0,33 & 2 & 0,33 & 2 & 0,32 & 2 \\
\hline
\end{tabular}

*Таблицю сформовано авторами за даними Державної служби статистики України (Derzhstat Ukrainy, 2018; Derzhstat Ukrainy, 2020b);

**У графі “Частка, \%” наведено значення коефіцієнту використання місткості.

3 даних табл. 4 видно, що Львівська область значно випереджає навіть най блищу за рангом Одеську область (частка досліджуваних показників Одещини коливається в межах 5,9\% - 9,2 \%, тоді як Львівщини у межах 13,4\%-18,1\%). Львівщина поступається лише Київській області, якій належить перше місце, що цілком логічно, оскільки столиця за своїм статусом має більші за обсягом туристичні потоки порівняно з іншими регіонами України. 


\section{Таблиця 4}

Позиціювання готельного сектору Львівської області серед інших областей України за 2019 р.*

\begin{tabular}{|c|c|c|c|c|c|c|}
\hline \multirow{2}{*}{\multicolumn{2}{|c|}{ Показник }} & \multicolumn{5}{|c|}{ Ранг окремих областей України } \\
\hline & & \multirow{2}{*}{$\frac{\mathrm{I}}{\text { Київська }}$} & \multirow{2}{*}{$\begin{array}{c}\mathrm{II} \\
\text { Львівська }\end{array}$} & \multirow{2}{*}{$\frac{\text { III }}{\text { Одеська }}$} & \multirow{2}{*}{$\frac{\mathrm{IV}}{\text { Дніпропетровська }}$} & \multirow{2}{*}{$\frac{\mathrm{V}}{3 \text { 3anopiзькa }}$} \\
\hline 1.Кількість готелів & Область & & & & & \\
\hline $\begin{array}{l}\text { та аналогічних засо- } \\
\text { бів розміщування }\end{array}$ & Частка, \% & 18,3 & 13,4 & 9,1 & 7,4 & 6,2 \\
\hline \multirow{2}{*}{$\begin{array}{l}\text { 2. Загальна кількість } \\
\text { місць }\end{array}$} & Область & Київська & Львівська & Одеська & $\begin{array}{l}\text { Івано-Франківська, } \\
\text { Дніпропетровська }\end{array}$ & Закарпатська \\
\hline & Частка, \% & 25,6 & 15,1 & 9,2 & 5,9 & 4,8 \\
\hline \multirow{2}{*}{$\begin{array}{l}\text { 3.Загальна кількість } \\
\text { обслуговуваних } \\
\text { приїжджих }\end{array}$} & Область & Київська & Львівська & Одеська & Дніпропетровська & Харківська \\
\hline & Частка, \% & 38,1 & 14,0 & 5,9 & 4,9 & 4,2 \\
\hline \multirow{2}{*}{$\begin{array}{l}\text { 4.Кількість обслуго- } \\
\text { вуваних іноземців }\end{array}$} & Область & Київська & Львівська & Одеська & Харківська & $\begin{array}{l}\text { Івано-Франківська, } \\
\text { Дніпропетровська }\end{array}$ \\
\hline & Частка, \% & 63,7 & 14,7 & 6,2 & 3,1 & 1,7 \\
\hline \multirow{2}{*}{$\begin{array}{l}\text { 5. Кількість ночівель } \\
\text { осіб }\end{array}$} & Область & Київська & Львівська & Одеська & Дніпропетровська & $\begin{array}{c}\text { Івано-Франківська, } \\
\text { Харківська }\end{array}$ \\
\hline & Частка, \% & 34,1 & 18,1 & 6,2 & 4,8 & 4,3 \\
\hline \multirow{2}{*}{$\begin{array}{l}\text { 6. Кількість ночівель } \\
\text { іноземців }\end{array}$} & Область & Київська & Львівська & Одеська & Харківська & Дніпропетровська \\
\hline & Частка, \% & 56,7 & 17,5 & 7,8 & 4,0 & 2,2 \\
\hline \multirow{2}{*}{ 7. Кількість номерів } & Область & Київська & Львівська & Одеська & Дніпропетровська & Івано-Франківська \\
\hline & Частка, \% & 26,6 & 14,3 & 8,7 & 6,2 & 5,3 \\
\hline \multirow{2}{*}{$\begin{array}{l}\text { 8. Коефіцієнт вико- } \\
\text { ристання місткості }\end{array}$} & Область & Київська & $\begin{array}{c}\text { Львівська, } \\
\text { Хмельницькка }\end{array}$ & $\begin{array}{l}\text { Полта- } \\
\text { вська }\end{array}$ & $\begin{array}{l}\text { Чернівецька, } \\
\text { Чернігівська }\end{array}$ & Житомирська \\
\hline & Значення & 0,34 & 0,32 & 0,30 & 0,28 & 0,27 \\
\hline
\end{tabular}

*Джерело: Показники таблиці розраховано авторами за даними Державної служби статистики України (Derzhstat Ukrainy, 2020b)

Частка Львівської області за кількістю місць в готелях та аналогічних засобах розміщування у 2019 році складає 15,1 \% (2 місце), що значно більше ніж в Одеській обл. - 9,2 \% (3 місце). Найбільшу частку серед інших областей України (крім Київської) протягом 2017-2019 рр. Львівщина займає за показником кількості ночівель $(18,0 \%-18,7 \%)$, значно випереджаючі Одещину, частка якої у 2019 р. складає 6,2 \%. При цьому за кількістю туристів частка Львівщини складає 14,0 \%, а Одещини 5,9 \%. Це свідчить про те, що туристи у Львівській області залишаються довше і цей регіон знаходиться в центрі їх уваги (після Київської області). Співвідношення частки кількості іноземців та частки кількості їх ночівель в Київській обл. $(63,7 \% / 56,7 \%)$ та у Львівській обл. (14,7 \%/17,5 \%) говорить про те, що іноземні туристи, які перебували у Львові схильні до більш тривалого перебування, ніж іноземні туристи у Києві.

Середньорічне значення коефіцієнту використання місткості готелів та аналогічних засобів розміщування складає по Львівській області у 2018/2019 pp. 0,32/0,33, що є вищим від значення цього показника по Україні загалом $(0,28 / 0,27)$. Коефіцієнт використання місткості для Київської області у 2019 р. складає 0,34 (1 місце), для Полтавської області 0,30 (3 місце). Отже Львівська область за значенням цього показника знаходиться поруч з Київською обл. Для порівняння, середньорічне значення коефіцієнта використання місткості у 2019 в ЄС склало 0,50. Найбільше значення цього показника у 2019 р. було зафіксовано на Кіпрі $(0,72)$, Мальті $(0,66)$, Іспанії $(0,61)$, Хорватії (0,60) (Eurostat, 2020). Протягом 2018-
2019 рр. в ЄС коефіцієнт використання місткості коливався у межах 0,37-0,40 у непіковий сезон і 0,630,67 у піковий сезон (у липні-серпні) (Eurostat, 2020). Це свідчить про нижчий рівень використання місткості готелів в Україні порівняно з СС і, відповідно, про наявний потенціал цього сектору інфраструктури туризму України та Львівщини зокрема щодо можливостей обслуговування більшого обсягу туристичних потоків.

Територіальна нерівномірність розподілу туристичних потоків, яка є в Україні, притаманна також і СС. Так, за даними Євростату у 2019 році $39 \%$ всіх ночівель в колективних засобах розміщування ЄС припадає на 20 регіонів. 52,7\% всіх ночівель в колективних засобах розміщування ЄС припадали на внутрішній туризм, 28,3 \% на туристів із інших країн СС і 19,0 \% на туристів з інших країн крім СС. Найбільш активними в 2019 році в ЄС були туристи з Німеччини (Eurostat, 2020). В Україні у 2019 р. серед іноземців, які перебували у готелях та аналогічних засобах розміщування, найбільша частка туристів припадала на США (9,1 \%), Польщу $(9,1 \%)$, Німеччину $(8,2 \%)$, Туреччину (7,3 \%), Ізраїль (6,1 \%). В Україні у 2019 році частка ночівель внутрішніх туристів у загальній кількості ночівель склала 77,2 \%, у Львівській обл. $77,9 \%$.

\section{4. Перспективи розвитку сільських готелів}

Всесвітня туристична організація (ВТО) відзначає, що сільський туризм має достатній потенціал на ринку туристичних послуг. За оцінками 3 \% усіх міжнародних туристів повязано з сільським туризмом. Про- 
явом значної уваги з боку ВТО до цього виду туризму свідчать міжнародні зустрічі, присвячені цій тематиці. Зокрема, це семінари “Сільський туризм в Європі: досвід та перспективи” (Белград, 2002 р.), “Сільський туризм в Європі: шлях до сталого розвитку” (Польща, 2003р.), “Сільський туризм в Свропі: керівні принципи розвитку туризму” (Україна, Яремче, 2003 р.). У зазначених семінарах брали участь представники близько 20 країн Західної, Центральної та Східної Європи, декілька міжнародних організацій та представлений широкий спектр досвіду (WTO, 2004). Учасники семінарів повідомили про позитивний вплив сільського туризму на розвиток сільських територій. Цей вплив проявляється насамперед у тому, що сільський туризм створює додаткове джерело доходів по відношенню до доходів від сільського господарства та тваринництва, сприяє розвитку підприємництва у суміжних сферах (торгівля, зони відпочинку та ін.), знижує швидкість скорочення сільських районів, сприяє відновленню та збереженню народних промислів, відновленню історичних споруд.

Крім того, за прогнозами ООН до 2050 р. 68 \% населення будуть мешкати у містах. Тому на 13-му самміті ВТО у 2019 р. “Технології для розвитку сільських територій” сільський туризм був оголошений як ключовий інструмент подолання розриву між сільськими та міськими районами за рахунок створення робочих місць та підвищення економічної стабільності. Про значну увагу з боку ВТО до сільського туризму на сучасному етапі свідчить також той факт, що темою Всесвітнього дня туризму (27 вересня) у 2020 р. було оголошено "Розвиток сільських територій та туризму” (Hospitalitynet, 2019). Статистичні дані Свростату підтверджують зростання інтересу до сільського туризму з боку туристів. Так у 2019 р. 32,9 \% від загальної кількості ночівель туристів СС припадало на сільську місцевість. Найбільшим серед країн ЄС цей показник був у Греції (66,8 \%), Австрії (65,6\%), Хорватії (63,4 \%) та Данії (52\%) (Eurostat, 2020).

Розвиток сільського туризму (як і інших видів туризму) неможливий без наявності засобів розміщування, до яких також відносять агрооселі та агроготелі. В Україіні за період 2011-2017 рр. такий вид колективних засобів розміщування як агроготелі відсутній (Derzhstat Ukrainy, 2018). Сільський туризм здійснюється на основі агросадиб, відповідно, розміщування туристів відбувається здебільшого в агрооселях і в сільських готелях. У 2017 р. в Україні налічувалось 377 садиб, з них в Івано-Франківській обл. - 306, у Чернівецькій обл. - 16, у Львівській обл. - 14. Частка доходів садиб України в доходах усіх колективних засобів розміщування фізичних осіб-підприємців за 2017 р. склала 3,4 \% (у сумі 53,6 млн. грн.). Очевидно, що відсутність агроготелів повязана 3 недостатнім рівнем розвитку сільського туризму в Україні. Здійснення готельного бізнесу на сільських територіях потребує з одного боку - збільшення туристичного потоку, а з другого боку - вкладення більших інвестицій (звісно, у сучасних реаліях в основному за рахунок власних коштів господарів садиб). Дослідження Engeset (2020) показує, що економічна стійкість сіль- ських готелів власне залежить здебільшого від сімейного капіталу.

У звязку із карантинними обмеженнями на виїзд за кордон в багатьох країнах різко зріс попит на внутрішній туризм, зокрема і на сільський туризм також. Так, P. P. William, директор по стратегіï доходів "Revenue Matters" та незалежний фінансовий консультант по проєктах розвитку готелів, повідомляє про різке зростання бронювань на літо і осінь 2020 р. для сільських готелів США. За його словами деякі власники навіть розмірковують над можливостями нарощування потужностей свого бізнесу. На думку P. P. William у сільських готелів може зявитись можливість мати щонайменше ще один сезон високого попиту літом 2021 р. А на перспективу, коли світ почне відкриватись, структура попиту та алгоритми управління доходами знову почнуть змінюватись на користь інших ринків. Разом 3 тим він не виключає можливості підвищення попиту на послуги сільських готелів порівняно з докарантинним рівнем за умови проведення ефективної маркетингової роботи 3 клієнтами (CoStar, 2020b).

Історичний досвід показує, що кожна криза зрештою створює нові можливості для туризму. Так, під час фінансової кризи-2008 р. продаж традиційних турпакетів знизився, але почали розвиватись сервіси сумісного використання нерухомості та інших послуг, такі як Airbnb, BlaBlaCar та інші, які дозволяють споживачам мандрувати економно. На думку Travelмаркетолога О. Білоусової масовий туризм буде перетворюватись на більш індивідуальний, популярність пакетного туризму буде знижуватись через побоювання щодо безпеки відпочинку у великих готельних комплексах (Interfaks, 2021). Отже, враховуючи зазначені фактори сучасного стану ринку туризму, вважаємо, що сільські готелі за умови (1) реалізації державної підтримки колективних засобів розміщування (розробленої з врахуванням досвіду виходу з фінансової кризи-2008 готельного сектору країн СС) та (2) запровадження ефективної маркетингової політики, мають непогані перспективи для подальшого успішного розвитку.

\section{Висновки}

Результати проведеного дослідженняв показують, що готелі та аналогічні засоби розміщування у Львівській області серед інших колективних засобів розміщування займають більшу частку за основними показниками порівняно з іншими регіонами України. Аналіз показав, що займаючи 2 місце в Свропі за площею території, Україна за кількіостю готелів та аналогічних засобів розміщування посідає 10 позицію та 22 позицію за кількістю місць серед країн СС. При цьому зростання кількості готелів по Україні відбувається повільними темпами, що пояснюється цілою низкою причин. Досвід зарубіжних країн з високим рівнем розвитку готельного сектору показує, що для досягнення таких результатів застосовується державне регулювання. Отже, для розвитку готельного сектору в Україні необхідним є розроблення програми його підтримки на державному рівні. Зокрема, на нашу 
думку, необхідно використовувати інструменти фіскального стимулювання (наприклад, зниження ставки ПДВ для готельного сектора). Фіскальне стимулювання може бути застосувано також для збільшення туристичного потоку (наприклад, відшкодування ПДВ для іноземних туристів за придбані товари, зниження ставок ПДВ на транспортні перевезення пасажирів). Враховуючи наявні протиріччя фіскального законодавства, доцільним є також розроблення ефективного механізму податкового стимулювання малого бізнесу, оскільки діяльність 3 надання послуг тимчасового розміщування здійснюється в основному субєєками малого підприємництва.

Перспективи подальших досліджень. Важливим напрямом подальших досліджень є детальне вивчення досвіду фіскального стимулювання сфери гостинності країн СС, впроваджене під час фінансової кризи-2008, 3 метою його адаптації та впровадження до української практики.

\section{References}

2019 Global Hotel Study (2020). CoStar Realty Information, Inc. URL: https://str.com/sites/default/files/global-hotelstudy-report-2019-2020.pdf (data zvernennia: 10.09.2021).

2019-2020 HOTREC Annual Report (2020). URL: https:/www.hotrec.eu/wp-content/customer-area/ storage/2a9c96707e5cde647bb9f60b763b4fe2/0520Hotrec-Annual-Report-07.pdf (data zvernennia: 10.09.2021).

Ahn, Y. H., \& Pearce, A. R. (2013). Green luxury a case study of two green hotels. Journal of Green Building, 8(1), 90-119. doi: 10.3992/jgb.8.1.90.

Anguera-Torrell, O., Aznar-Alarcón, J. P., \& Vives-Perez, J. (2020). COVID-19: hotel industry response to the pandemic evolution and to the public sector economic measures. Tourism Recreation Research, 46(2), 148157, doi: 10.1080/02508281.2020.1826225.

Arbelo, A., Pérez-Gómez, P., González-Dávila, E., \& Rosa-González, F. M. (2017). Cost and Profit Efficiencies in the Spanish Hotel Industry. Journal of Hospitality \& Tourism Research, 41(8), 985-1006. doi: 10.1177/1096348015587999.

Baicu, C. G., Oehles-Sincai, I. M., State, O. \& Popescu, D. (2019). Bioeconomy and Social Responsibility in the Sustainable Hotel Industry. Amfiteatru Economic, 21(52), 639-653. doi: 10.24818/EA/2019/52/639.

Botta, M. (2019). Financing Decisions and Performance of Italian SMEs in the Hotel Industry. Cornell Hospitality Quarterly, 60(4), 335-356. doi: 10.1177/ 1938965518816948.

Bowie, D. (2018). Innovation and $19^{\text {th }}$ century hotel industry evolution. Tourism Management, 64, 314-323, doi: 10.1016/j.tourman.2017.09.005.

Casado-Díaz, A. B., \& Sellers-Rubio, R. (2020). The effect of short-term rentals on regional hotel efficiency. Current Issues in Tourism, 24(21), 2990-2995 doi: $10.1080 / 13683500.2020 .1857348$.

STR: US Hotel Revenues Surpassed \$200 Billion in 2017. (2020). CoStar. URL: https://www.costar.com/ article/1312466822.
American Mindset Driving Demand in Rural Hotels. (2020). CoStar. URL: https://www.costar.com/ article/1746276950.

United States (USA) GDP - Gross Domestic Product. (2020). URL: https://countryeconomy.com/ gdp/usa?year=2017.

Derzhstat Ukrainy (2011). Metodolohichni polozhennia zi statystyky turyzmu. Kyiv. Ukraina.18 p. URL: https://ukrstat.org/uk/metod_polog/menu/07_posl.htm (in Ukrainian).

Derzhstat Ukrainy (2018). Kolektyvni zasoby rozmishchuvannia v Ukraini u 2017 rotsi. Statystychnyi zbirnyk. Vidpovidalnyi za vypusk O.O. Karmazina. Kyiv. URL: http://www.ukrstat.gov.ua/ druk/publicat/kat_u/2018/zb/05/zb_kzr_2017.pdf (in Ukrainian).

Derzhstat Ukrainy (2020a). Osnovni pokaznyky diialnosti kolektyvnykh zasobiv rozmishchuvannia v Ukraini u 2019 rotsi (z urakhuvanniam diialnosti fizychnykh osib-pidpryiemtsiv). URL: http://www.ukrstat.gov.ua/ operativ/operativ2020/tyr/kol_zas_ukr/kol_zas_rozm_ 2020_u.htm (in Ukrainian).

Derzhstat Ukrainy (2020b). Kolektyvni zasoby rozmishchuvannia v Ukraini (2018-2019rr.). URL: https://ukrstat.org/uk/operativ/operativ2019/tyr/kol_za s_ukr/arch_kol_zas_ukr.htm (in Ukrainian).

Dogru, T., McGinley, S. \& Kim, W. G. (2020). The effect of hotel investments on employment in the tourism, leisure and hospitality industries. International Journal of Contemporary Hospitality Management, 32(5), 1941-1965. doi: 10.1108/IJCHM-11-2019-0913.

Engeset, A. B. (2020). "For better or for worse" - the role of family ownership in the resilience of rural hospitality firms. Scandinavian Journal of Hospitality and Tourism, 20(1), 68-84. doi: 10.1080/15022250.2020.1717600.

DSTU 4527:2006 (2006). Natsionalnyi standart Ukrainy. Posluhy. Turystychni zasoby rozmishchennia. Terminy ta vyznachennia. URL: https://hihostels.com.ua/ sites/default/files/hostely/dstu4527.pdf (in Ukrainian).

Eurostat (2014). Methodological manual for tourism statistics. Version 3.1. URL: https:/ec.europa.eu/eurostat/documents/ 3859598/6454997/KS-GQ-14-013-EN-N.pdf/166605aa-c99040c4-b9f7-59c297154277?t=1420557603000.

Eurostat (2020). Tourism statistics - annual results for the accommodation sector. URL: https://ec.europa.eu/eurostat/statisticsexplained/index.php/Tourism_statistics - annual results

for_the_accommodation_sector\#Average_occupancy_rate_of bed_places_in_hotels_was_50.C2.A0.25.

FoodDrinkEurope (2020). Temporarily reduced VAT rates for hospitality services. URL: https:/www.hotrec.eu/wp-content/customerarea/storage/567b52abba7d6ff356cbaa210e841180/D1020-371-Position-Paper-Temporarily-reduced-VATrates-for-hospitality-services-21102020.pdf.

Fortanier, F. \& van Wijk, J. (2010). Sustainable tourism industry development in sub-Saharan Africa: Consequences of foreign hotels for local employment. International Business Review, 19(2), 191-205. doi: 10.1016/j.ibusrev.2009.11.007.

Gursoy, D. \& Chi, C. G. (2020). Effects of COVID-19 pandemic on hospitality industry: review of the current situations and a research agenda. Journal of Hos- 
pitality Marketing \& Management, 29(5), 527-529. doi: 10.1080/19368623.2020.1788231.

He, P., Qiu, Yu., Wang Yi D., Cobanoglu, C., Ciftci, O. \& Liu, Z. (2019). Loss of profit in the hotel industry of the United States due to climate change. Environmental research letters, 14(8), 084022. doi: 10.1088/17489326/ab2dce.

Herasymenko, V. H., Bedradina, H. K., Halasiuk, S. S., Halasiuk, K. A., Davidenko, I. V., Yehupova, I. M. ta in. (2016). Otsinka turystychno-rekreatsiinoho potentsialu rehionu: monohrafiia. Odesa. ONEU (in Ukrainian).

Holovne upravlinnia satystyky u Lvivskii obl. (2018). Makroekonomichni pokaznyky. Valovyi rehionalnyi produkt za 2010-2018 gg. URL: https://www.lv.ukrstat.gov.ua/ukr/themes/01/theme_0 1.php? code $=01$ (in Ukrainian).

Hospitalitynet (2019). Innovation and Rural Development Takes Center Stage For Ministers' Summit at World Travel Market. URL: https://www.hospitalitynet.org/ news/4095735.html.

Hotel management (2020). URL: https://www.hotelmanagement. nethuman-resources/hotel-industry-accounts-for-more-than1-25-u-s-jobs.

Interfaks (2021). Kogda turisty snova smogut puteshestvovat i kak budet vyglyadet turizm posle pandemii. URL: https:/www.interfax.ru/world/ 703736 (in Russian).

Kalaitan, T. V. (2020). Faktornyi analiz v upravlinni dokhodnistiu pidpryiemstv hotelnoho biznesu. Pidpryiemnytstvo i torhivlia, 26, 37-44. URL: http://www.journals-lute.lviv.ua/index.php/pidprtorgi/article/view/104 (in Ukrainian).

Kalaitan, T. V., Stybel, V. V., Gutyj, B. V., Hrymak, O. Ya., Kushnir, L. P., Yaroshevych, N. B., Vovk, M. V., Kindrat, O. V. (2021). Ecotourism and sustainable development. Prospects for Ukraine. Ukrainian Journal of Ecology, 11(1), 373-383. doi: 10.15421/2021_55.

Karanovic, G., Karanovic, B. \& Stambuk, A. (2018). Financial Analysis as a Measure of Risk Management in Croatia's Hotel Industry. KnE Social Sciences, 3(10), 88-106. doi: 10.18502/kss.v3i10.3532.

Kontakty (2020). Bereshchak, V. Obzor rynka otelei: chto proyskhodyt $\mathrm{s}$ hostynytsamy $\mathrm{V}$ Ukrayne. URL: https://thepage.ua/exclusive/obzor-rynka-otelej-chtoproishodit-s-gostinicami-v-ukraine (in Russian).

Larrinaga, C., \& Vallejo, R. (2021). The origins and creation of the tourist hotel industry in Spain from the end of the 19th century to 1936 . Barcelona as a case study. Tourism Management, 82, 104203. doi: 10.1016/ j.tourman.2020.104203.

Li, X. (2015). Risk Evaluation on Rural Hotel Investment and Preventive Measures. Advances in Social Science Education and Humanities Research, 22, 471-478. doi: 10.2991/icetem-15.2015.71.

Mak, A. H. N., \& Chang, R. C. Y. (2019). The driving and restraining forces for environmental strategy adoption in the hotel Industry: A force field analysis approach. Tourism Management, 73, 48-60. doi: 10.1016/j.tourman.2019.01.012.

Mariño-Romero, J. M., Campón-Cerro, A. M., Hernández-Mogollón, J. M., \& Folgado-Fernández, J. A.
(2018). The Relationship Between Revenue and Environmental Responsibility: A Causal Study Using Reputation in the Hotel Industry. Sustainability in Innovation and Entrepreneurship. Innovation, Technology, and Knowledge Management. Springer, 119-136. doi: 10.1007/978-3-319-57318-2_8.

Melián-González, S., \& Bulchand-Gidumal, J. (2020). Employment in tourism: The jaws of the snake in the hotel industry. Tourism Management, 80, 104-123 doi: 10.1016/j.tourman.2020.104123.

Minfin (2021). Valovyi vnutrishnii produkt (VVP) V Ukraini 2021. URL: https://index.minfin.com.ua/ua/ economy/gdp (in Ukrainian).

Moldovanov, M. I. \& Tkachuk, O. L. (2017). Adaptive development of hotel business. Aktualni problemy innovatsiinoho rozvytku klasternoho pidpryiemnytstva v Ukraini: materialy Vseukr. nauk.-prakt. konf. (30 bereznia 2017 r., m. Kyiv). K.: KNUTD, 80-89.

Mun, S. G., Woo, L., \& Paek, S. (2019). How important is $\mathrm{F} \& \mathrm{~B}$ operation in the hotel industry? Empirical evidence in the US market. Tourism Management, 75, 156-168. doi: 10.1016/j.tourman.2019.03.010.

Nakaz Derzhstatu Ukrainy (2018) vid 16.07.2018 №152. URL: http://www.ukrstat.gov.ua/norm_doc/2018/152/ 152_2018.htm (in Ukrainian).

Papadopoulos, O., \& Lyddon, D. (2020). Deregulation and institutional conversion in the Greek hotel industry: an employment relations model in transition. Industrial Relations Journal, 51(1-2), 92-109. doi: 10.1111/irj.12282.

Pricewaterhouse Coopers LLP (PwC) (2017). The Impact of Taxes on the Competitiveness of European Tourism. URL: https:/www.europarl.europa.eu/ cmsdata/130660/The\%20Impact $\% 20$ of $\% 20$ Taxes $\% 20$ on $\% 20$ the $\% 20$ Competitiveness $\% 20$ of $\% 20$ European $\%$ 20tourism.pdf.

Serra-Cantallops, A., Peña-Miranda, D. D., José RamónCardona, J., \& Martorell-Cunill, O. (2018). Progress in Research on CSR and the Hotel Industry (20062015). Cornell Hospitality Quarterly, 59(1), 15-38. doi: 10.1177/1938965517719267.

Vargas-Hernández, J. G., \& Benítez, K. T. W. (2019). Analysis based on the industry of the hotel sector in Mexico: Posadas case. TURISMO-ESTUDOS E PRATICAS, 8(2), 41-58. doi: 10.31410/tmt.2019.559.

WTO (2004). Rural Tourism in Europe: Experiences, Development and Perspectives. URL: http://www.institutobrasilrural.org.br/download/20120 219145557.pdf.

Yaroshevych, N. B., Cherkasova, S. V., Kalaitan, T. V. (2019). Inconsistencies of small business fiscal stimulation in Ukraine. Journal of Tax Reform, 5(3), 204-219. doi: 10.15826/jtr.2019.5.3.068.

Zakon Ukrainy (2020). "Pro vnesennia zmin do Podatkovoho kodeksu Ukrainy shchodo derzhavnoi pidtrymky kultury, turyzmu ta kreatyvnykh industrii" vid 04.11.2020 №962-IX. URL: https://zakon.rada. gov.ua/laws/show/962-20\#Text (in Ukrainian).

Inozemtsi u lvivski hoteli ne investuiut, lyshe rosiiany (2020). URL: https://zaxid.net/inozemtsi_u_lvivski_ goteli_ne_investuyut_lishe_rosiyani_n1514695 (data zvernennia: 10.09.2021) (in Ukrainian). 